\title{
REVIEW
}

\section{Regional variation in the role of bottom-up and top-down processes in controlling sandeel abundance in the North Sea}

\author{
Morten Frederiksen $^{1, *}$, Robert W. Furness ${ }^{2}$, Sarah Wanless ${ }^{1}$ \\ ${ }^{1}$ Centre for Ecology and Hydrology, Hill of Brathens, Banchory AB31 4BW, UK \\ ${ }^{2}$ Institute of Biomedical and Life Sciences, University of Glasgow, Glasgow G12 8QQ, UK
}

\begin{abstract}
The lesser sandeel Ammodytes marinus is a critically important mid-trophic species in the North Sea ecosystem. Seabirds suffered widespread breeding failures in the North Sea in 2004, due to shortages of sandeels, their principal food. Industrial sandeel fisheries also failed in 2003 to 2005. Explaining why sandeels were in short supply is thus critical to understanding and managing the North Sea ecosystem. Sandeel abundance may be controlled 'bottom-up' by food availability or 'top-down' by predation, including fisheries. The relative importance of these 2 mechanisms may vary over space and time, and failure to take account of such variation may lead to inappropriate management. We summarise the available evidence for top-down or bottom-up control of sandeel abundance in 2 well-studied North Sea regions differing in many biotic and abiotic characteristics. In Shetland, recent low abundance of sandeels coincided with record-high abundance of herring, which may have exerted a top-down predation pressure on sandeels. Off SE Scotland, where adult herrings are scarce, abundance of sandeel larvae was positively correlated with plankton abundance, indicating bottom-up control. Seabird breeding failures in this area in 2004 were linked to extremely low energy content of sandeels. Large-scale sandeel fisheries have not been operating in either area since 2000. Control of food web structure and function in the North Sea is thus likely to be complex, with pronounced regional variation. Improved cooperation between diverse research organisations will be needed to understand this complexity, and future ecosystem-based management of marine bioresources will need to take the results of such research into account.
\end{abstract}

KEY WORDS: Ecosystem function - Herring - Marine food webs - Resource management · Sandeel · Trophic structure

Resale or republication not permitted without written consent of the publisher

\section{INTRODUCTION}

Many marine pelagic ecosystems have a relatively simple structure, with energy flow going from phytoplankton primary producers, through zooplankton (often dominated by copepods) to pelagic schooling fishes, and finally to a variety of top predators including fishes, marine mammals and seabirds (Jennings et al. 2001). The structure and function of such ecosystems may be regulated through 'bottom-up' effects, whereby the amount of primary production, often thought to be under nutrient and/or climatic control, determines the abundance at higher trophic levels, or through 'top-down' effects of predators, including human fisheries, on lower trophic levels (Cury et al. 2001; available at: ftp.fao.org/fi/document/reykjavik/ 
Default.htm). Recently, there has been strong interest in when and where each of these mechanisms is more important (Hunt et al. 2002, Worm \& Myers 2003, Munch et al. 2005, Scheffer et al. 2005, Ware \& Thomson 2005, Halpern et al. 2006). The dominant type of regulation in a specific ecosystem clearly has major implications for resource management and for inferring causes of observed changes in ecosystem components (Cury \& Shannon 2004, Hunt \& McKinnell 2006).

The North Sea is one of the most heavily fished regional seas in the world, and fisheries have undoubtedly had major impacts on ecosystem structure and function over several centuries. In heavily fished systems, trophic structure is simplified and food webs are shortened, probably leading to decreased resilience to environmental perturbations (Pauly \& Maclean 2003). Consistent with this hypothesis, rapid climate-driven changes have become apparent in recent years at all trophic levels in the North Sea (Edwards et al. 2002, Beaugrand 2004, Edwards \& Richardson 2004, Perry et al. 2005), including top predators such as seabirds (Frederiksen et al. 2004, Grosbois \& Thompson 2005). Most species of seabirds in the North Sea suffered widespread reproductive failures in 2003 and 2004 (Mavor et al. 2005). The most severe problems, including total failures of some species, occurred in Shetland and Orkney in the northernmost part of the North Sea, but in 2004 exceptionally low breeding success was also observed in colonies along the east coast of Britain (Harris et al. 2004, Mavor et al. 2005). Although inclement weather during the chick-rearing period was partly to blame at some colonies (S. Wanless, M.P. Harris \& M. Frederiksen pers. obs.), the main proximate cause of the breeding failures was a lack of high-quality food, i.e. small pelagic fishes with a high lipid content (Davis et al. 2005, Wanless et al. 2005). Most seabirds in the North Sea feed predominantly on lesser sandeels Ammodytes marinus (hereafter sandeels) during the breeding season (Wanless et al. 1998, Furness 2002). Since the 1970s, sandeels have been the dominant mid-trophic pelagics in the North Sea, and around Shetland no other high-lipid prey fishes occur in sufficient densities to support successful breeding of most piscivorous seabirds (Johnston 1999, Furness \& Tasker 2000). There is thus little doubt that the observed seabird breeding failures were linked to low availability of high-quality sandeel prey. Further evidence for the bad state of North Sea sandeel stocks comes from the large-scale industrial fishery: during the 1990s annual landings were 600000 to 1100000 metric tons (t), but in 2003 and 2004 they fell to around $300000 \mathrm{t}$, despite effort being maintained (ICES 2004). The fishery was closed completely by the European Commission from 15 July 2005 after real-time monitoring showed low catch per unit effort and very poor recruitment of the 2004 cohort (Anonymous 2005).

Recruitment to sandeel stocks in the southern North Sea has been shown to be negatively affected by high winter sea temperature (Arnott \& Ruxton 2002). Virtual population analysis (VPA) estimates show that sandeel recruitment was very low in 2002 to 2004 (ICES 2006). It thus seems obvious to link the problems that sandeel stocks (and in consequence breeding seabirds) experienced in 2003 and 2004 to regional climate change, and such a connection has indeed been made and widely publicised (e.g. Royal Commission on Environmental Pollution 2004). However, there is as yet no published evidence to show that high sea temperatures were associated with the observed sandeel recruitment failures in 2002 to 2004, and the exact mechanism through which climate affects sandeel recruitment is also unclear. While climate-driven bottom-up control of sandeel abundance is a plausible scenario, other explanations are possible and should be considered. Specifically, a 'new' source of possible top-down control has reappeared in the North Sea since 2000. Herring Clupea harengus, which feed on sandeel larvae as well as zooplankton, have increased from a spawning stock biomass of less than $100000 \mathrm{t}$ in the late 1970s to 2 million $t$ in 2004, a level not seen since they were reduced dramatically by overfishing in the 1960s (ICES 2005). Could this increase in herring have had an impact on sandeels? It is also clear that even within the North Sea, a relatively homogeneous shelf sea, there is extensive regional variation in (e.g.) bathymetry, climate, hydrography, community composition at all trophic levels and fishing pressure. This regional variation is likely to affect the relative importance of top-down and bottom-up mechanisms. Here, we summarise evidence for how food abundance, predation and fisheries have affected sandeel abundance in the North Sea, and discuss the relative importance of top-down and bottom-up control in 2 well-studied regions of the North Sea (Shetland and east Scotland), and how this influences patterns at the ecosystem level. We also provide suggestions as to how researchers may reach firmer conclusions on regulation of marine ecosystems, and how knowledge about ecosystem regulation can play a part in sustainable management of marine bioresources. The approach we take here reflects our perspective as vertebrate ecologists with particular interest in seabirds. We hope that this paper will generate debate about how the abundance of a key mid-trophic species is controlled, and the implications this has for research and management. 


\section{SANDEEL AND HERRING BIOLOGY}

Sandeels and herring are both small to mediumsized, high-lipid, schooling pelagic fishes feeding mainly on zooplankton, and both can be extremely numerous in temperate seas around NW Europe (Muus et al. 1999). Nevertheless, there are several fundamental differences between them. Herring are larger than sandeels, and they feed on sandeel larvae as well as on zooplankton (Last 1989), whereas sandeels feed largely on copepods (Reay 1986). While herring are pelagic throughout their lives, sandeels have a more complex life cycle. The adults spend most of the year buried in sandy sediments, and only emerge to feed during daylight hours in late spring and early summer, and briefly to spawn in mid-winter. The pelagic larvae hatch in early spring, and after metamorphosis around May the young 0-group fish establish a diurnal rhythm similar to that of the adults. They continue feeding until late summer. Sandeels are dependent on specific types of sandy sediments, and adults only occur in areas where such sediments are common (Wright et al. 2000). As a consequence, sandeels show pronounced population structuring within the North Sea (Pedersen et al. 1999), whereas the more nomadic herring belong to one large stock, the North Sea autumnspawning herring. Young herring predominantly develop in the southern and eastern North Sea, whereas adults concentrate in the northwest around Shetland for much of the year (ICES 2005). There is some evidence that the distribution of adult herring has shifted northward in recent years, consistent with both increasing sea temperatures and a northward shift in the copepod Calanus finmarchicus, an important prey item (Corten 2001). Both sandeels and herring have been heavily exploited by human fisheries, but in very different ways. Herring have for centuries been one of the most important fishes for human consumption in Europe, whereas sandeels have only been caught in large quantities since the development of 'industrial' fisheries for fishmeal and oil in the 1950s. During most of this period, the sandeel fishery has been concentrated on offshore banks in the central North Sea, outside the foraging range of most breeding seabirds. However, from 1990 a large sandeel fishery (up to $100000 \mathrm{t} \mathrm{yr}^{-1}$ ) developed in the Wee Bankie area off SE Scotland; this fishery was closed in 2000 after concern about the low breeding success of some seabirds (Camphuysen 2005). In contrast, sandeel fisheries around Shetland have always been relatively small-scale, and following local seabird breeding failures in the late 1980s closures and voluntary restrictions were implemented (P. Wright unpubl.).

\section{SANDEELS, HERRING AND SEABIRDS AROUND SHETLAND}

Sandeels comprise the only common high-lipid schooling fish around Shetland, and the breeding success of most species of seabirds is closely related to sandeel abundance (Hamer et al. 1993, Davis et al. 2005). This dependence is clearly illustrated by data on the breeding success of Arctic skuas Stercorarius parasiticus and black-legged kittiwakes Rissa tridactyla on the island of Foula (Fig. 1). The total stock biomass of sandeels around Shetland declined at the same time as the spawning stock biomass (SSB) of herring in the North Sea increased, and both showed large deviations from the long-term trends during the 1990s (Fig. 2). The comparison between sandeel biomass around Shetland and herring biomass in the whole North Sea is justified by the fact that a large proportion of the North Sea adult herring stock is concentrated around Shetland, particularly in summer and in recent years (Corten 2001, ICES 2005). Such a mirror-image pattern may indicate a top-down effect of herring predation on sandeel biomass (Cury et al. 2001; available at: ftp.fao.org/fi/document/reykjavik/Default.htm). It has long been known that sandeel larvae form an

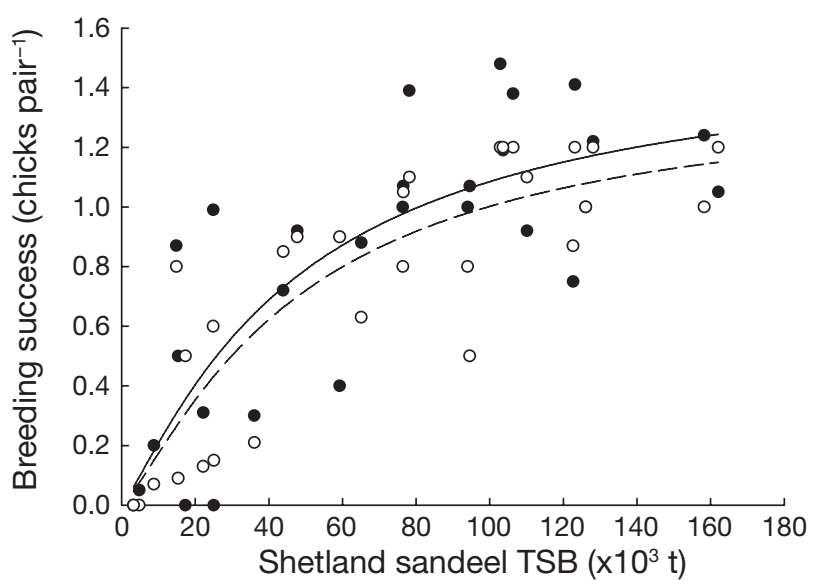

Fig. 1. Rissa tridactyla and Stercorarius parasiticus. Breeding success of black-legged kittiwakes $(\bullet, \longrightarrow)$ and Arctic skuas $\left(0_{1}---\right)$ at Foula, Shetland, during 1976 to 2004, showing strong positive correlation with total stock biomass (TSB) of sandeels Ammodytes marinus (logistic models: kittiwake breeding success $=1.5357 /\left(1+\left(\frac{\mathrm{TSB}}{47656}\right)^{-1.1853}\right), \mathrm{r}^{2}=0.65, \mathrm{p}<0.0001$; Arctic skua breeding success $=1.3977 /\left(1+\left(\frac{\mathrm{TSB}}{47633}\right)^{-1.2536}\right)$, $\left.r^{2}=0.73, p<0.0001\right)$. The 2 breeding success time series were also closely correlated $(r=0.86, p<0.001)$. Breeding success of the 2 species at Foula was representative of mean success in Shetland (data from Mavor et al. 2005) (kittiwake: $r=0.87$, $\mathrm{p}<0.001$; Arctic skua: $\mathrm{r}=0.90, \mathrm{p}<0.001$ ), but longer time series were available from Foula. Sandeel data derived by combining virtual population analysis (VPA) estimates for 1976 to 1994 (ICES 2002) with research survey data (Cook 2004 and pers. comm.) 


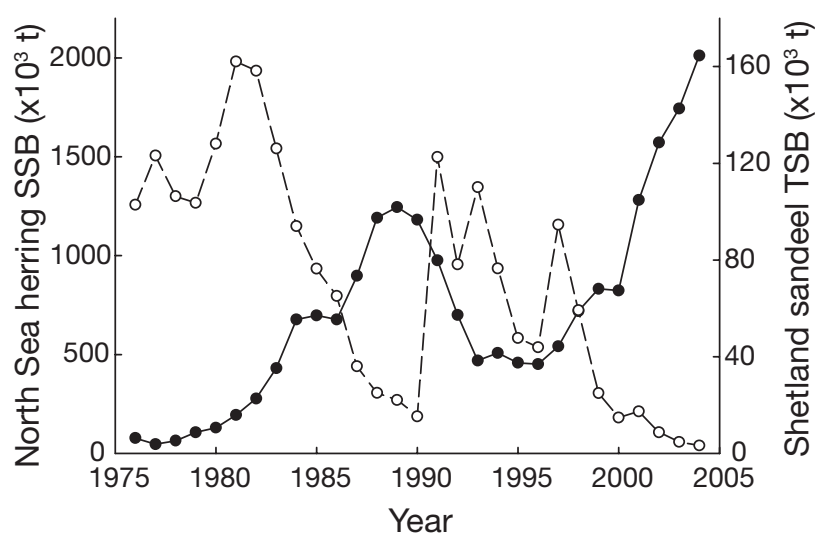

Fig. 2. Clupea harengus and Ammodytes marinus. Time series of North Sea herring spawning stock biomass (SSB, •) and Shetland sandeel total stock biomass (TSB, o) in 1976 to 2004, showing highly statistically significant negative correlation between herring and sandeel biomass $(r=-0.80, p<0.001)$. Both time series showed strong linear trends (herring: $\mathrm{r}=0.74, \mathrm{p}<$ 0.001 ; sandeel: $\mathrm{r}=-0.73, \mathrm{p}<0.001$ ), but the correlation between them remained significant after de-trending $(\mathrm{r}=-0.55, \mathrm{p}=$ 0.0019). Correlations persisted when 1 yr lag was introduced to account for sandeel TSB mainly consisting of $1 \mathrm{yr}$ old fish, and herring predation affecting larvae $(r=-0.74, \mathrm{p}<0.001$; after detrending $\mathrm{r}=-0.44, \mathrm{p}=0.016)$. There was no significant correlation between sandeel TSB around Shetland and sandeel landings in the North Sea $(r=0.21, p=0.35)$; de-trending or including a $1 \mathrm{yr}$ lag did not change this result. Herring data from ICES (2004), sandeel data derived by combining virtual population analysis estimates for 1976 to 1994 (ICES 2002) with research survey data (Cook 2004 and pers. comm.)

important part of herring diet in spring (Hardy 1924, Last 1989). At the same time, herring are generalist predators, and it is unlikely that bottom-up effects of the abundance of one particular prey species, such as sandeels, would be an important determinant of herring stock size. Herring predation has previously been shown to affect stocks of another small pelagic, the capelin Mallotus villosus in the Barents Sea (Gjøsæeter \& Bogstad 1998). North Sea herring total stock biomass rose from $250000 \mathrm{t}$ in 1977 to 3.6 million $\mathrm{t}$ in 2004 (ICES 2005). Spawning stock biomass, which is concentrated in the northwest, rose to 2 million $\mathrm{t}$ in 2004. Dommasnes et al. (2004) estimated a consumption to biomass ratio of 4.5 for herring, with most consumption in spring and summer. This implies consumption of 9 million $t$ of food by mature North Sea herring in 2004. If post-larval sandeels represented $10 \%$ of this (Last [1989] found that $23 \%$ of North Sea herring diet in May was post-larval sandeels), this would imply a consumption of $900000 \mathrm{t}$ of sandeels by mature herring in 2004, predominantly in the NW North Sea.

Other factors are also known to influence the abundance of Shetland sandeels. The extremely low sandeel biomass in 1987 to 1990, and by implication the seabird breeding failures observed during these years (Hamer et al. 1993, this study), has been attributed to few sandeel larvae drifting in from spawning grounds around Orkney due to failure of the Fair Isle current (Proctor et al. 1998). It is unclear whether similar oceanographic events have played a role in the recent lack of sandeels. Human fisheries are unlikely to have had a major impact on Shetland sandeels in recent years. The Shetland fishery was never large $(<7000$ t in 1980s); it was closed from 1990 to 1995, and in most years since 1995 the annual catch has been less than 3000 t, at least 2 orders of magnitude less than the probable consumption of sandeels by herring.

\section{SANDEELS, PLANKTON AND SEABIRDS OFF EAST SCOTLAND}

Further south in the North Sea, off SE Scotland and NE England, sandeels are also the main prey of most seabird species (Wanless et al. 1998). Sandeels in this area constitute a self-contained aggregation with only limited contact with other aggregations (Gallego et al. 2004); this is reflected in black-legged kittiwake breeding success, which is correlated among colonies in this region, but not with other regions (Frederiksen et al. 2005). In contrast to Shetland, other fish prey is also available, and in particular young clupeids (mainly sprat Sprattus sprattus) are taken in some years by seabirds (Bull et al. 2004, Harris et al. 2004, Wilson et al. 2004). However, few adult herring occur in this part of the North Sea (ICES 2005). There are no long-term data on sandeel abundance in this area, but during the 1990s local sandeel biomass was reduced by an industrial fishery, and this was associated with low breeding success of black-legged kittiwakes on the Isle of May in the Firth of Forth (Rindorf et al. 2000). Sandeel abundance and black-legged kittiwake breeding success increased following the closure of the fishery in 2000, but a similar effect was not seen for other seabird species (Daunt et al. unpubl. data). Recently, we used 'Continuous Plankton Recorder' (CPR) data to develop an index of abundance of sandeel larvae, and this index was positively correlated with the breeding success of 4 seabird species in the following year, suggesting a dependence on $1 \mathrm{yr}$ old sandeels (Frederiksen et al. 2006). The sandeel larval index was also strongly positively related to the abundance of phyto- and zooplankton, suggesting strong bottom-up control (Frederiksen et al. 2006). The index tended to be low during the 1990s, but whether this was related to the sandeel fishery is not clear.

In 2004, breeding success was exceptionally low for most seabird species on the Isle of May, despite sandeel larvae being abundant in the spring of 2003. Detailed studies showed that the energy content of 
both sandeels and sprat fed to seabird chicks in 2004 was extremely low, indicating poor food availability for the fish (Wanless et al. 2005). There is thus evidence suggesting that both abundance and quality of seabird prey is under bottom-up control in this region, which is likely to have affected seabird breeding success. A large-scale industrial fishery probably reduced sandeel abundance and consequently breeding success of some seabird species during the 1990s in this region (Rindorf et al. 2000, Frederiksen et al. 2004), but this fishery has been closed since 2000. Since much of the fishery effort was displaced just outside the closed area, the spatial overlap with seabird foraging areas was strongly reduced (Daunt et al. unpubl. data), and the fishery is unlikely to have affected sandeel availability to seabirds in 2004 .

\section{TOP-DOWN AND BOTTOM-UP CONTROL AT THE NORTH SEA ECOSYSTEM LEVEL}

Sandeel spawning stocks mainly consist of 2 yr old fish (ICES 2002), and are thus expected to be influenced by the strength of recruitment with a 2 yr lag. VPA estimates of sandeel SSB in the North Sea for 1983 to 2004 (ICES 2004) were negatively correlated with herring SSB 2 yr previously ( $\mathrm{r}=-0.54, \mathrm{p}=0.0099$ ), indicating the possibility of top-down control of larval abundance. Our tentative estimate that herring may have consumed at least $900000 \mathrm{t}$ of sandeels in 2004 is consistent with this. There was no correlation between North Sea sandeel SSB and the CPR-based index of sandeel larval biomass off east Scotland 2 yr previously $(\mathrm{r}=-0.10, \mathrm{p}=0.67)$. This lack of correlation may reflect differences in the spatial scale of the variables: the larval index is specific to 1 sandeel aggregation off east Scotland (Frederiksen et al. 2005), whereas the SSB estimates fail to account for population structure within the North Sea (Pedersen et al. 1999) and may be primarily determined by conditions on the main fishing grounds in the central North Sea. This emphasises that different processes may regulate sandeel abundance in different parts of the North Sea.

Ecosystem control of the North Sea food web is likely to be complex, although less complex than in the past (Pauly \& Maclean 2003). To illustrate this complexity, we focus on the relationships between sandeels and herring, their prey and human fisheries (Fig. 3). The proximate cause of the low sandeel abundance and fishery landings in 2003 to 2005 seems to have been recruitment failures (ICES 2006), but these failures could have been driven by either top-down or bottomup processes. It is not clear whether fisheries have depressed sandeel abundance in the wider North Sea: estimated stock size was stable despite high landings

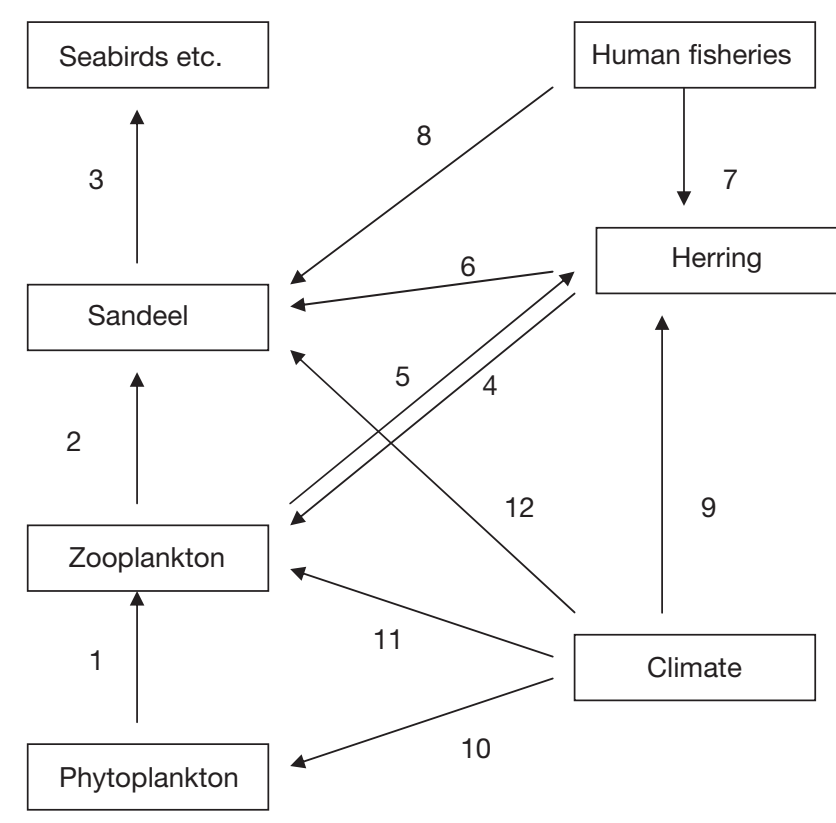

Fig. 3. Simplified diagram of some documented and probable trophic and climatic controls in the North Sea pelagic ecosystem. 1: bottom-up control of zooplankton by phytoplankton (Richardson \& Schoeman 2004); 2: bottom-up control of sandeel larvae by zooplankton (Frederiksen et al. 2006); 3: bottom-up control of seabird breeding success by sandeels (Hamer et al. 1993, Frederiksen et al. 2006, this study); 4: topdown control of zooplankton by herring predation (Arrhenius 1997); 5: bottom-up control of herring by zooplankton (Corten 2001, Beaugrand 2004); 6: top-down control of sandeels by herring predation (this study); 7: top-down control of herring by human fisheries (Jennings et al. 2001); 8: local top-down control of sandeels by human fisheries (Rindorf et al. 2000); 9: climatic control of herring recruitment (Sætre et al. 2002); 10 and 11: climatic control of phyto- and zooplankton (Edwards \& Richardson 2004, Hays et al. 2005); 12: climatic control of sandeel recruitment (not known if direct) (Arnott \& Ruxton 2002)

for more than $20 \mathrm{yr}$, and landings constituted only a minor fraction of the total consumption of sandeels (Furness 2002). Nevertheless, depletion by fisheries may have been important on a local scale, such as off SE Scotland (Rindorf et al. 2000). While there is some evidence of a top-down effect of herring on sandeels, herring abundance may itself be influenced by several factors, including top-down, bottom-up and direct climatic effects. Human fisheries have exerted a strong top-down control on herring stocks, which were reduced to a fraction of their previous abundance (e.g. Jennings et al. 2001), but have recovered following fishery restrictions. It seems likely that plankton abundance will affect both growth and survival of herring larvae and recruitment to the spawning stock (Jennings et al. 2001, Beaugrand 2004), as well as the distribution of adults (Corten 2001). Climate may also affect herring directly: for the Norwegian spring- 
spawning herring stock, recruitment is affected by oceanographic conditions determining retention and drift of larvae (Sæetre et al. 2002). It is also possible that herring exert top-down control of zooplankton abundance in the North Sea, as has been observed in the Baltic Sea (Arrhenius 1997) and inferred in the Norwegian Sea (Dommasnes et al. 2004). The abundance and phenology of both phyto- and zooplankton are strongly influenced by climatic factors (Edwards \& Richardson 2004, Richardson \& Schoeman 2004), and zooplankton abundance during critical periods would be expected to have a strong impact on sandeel growth and survival (Frederiksen et al. 2006). Fig. 3 only shows a very simplified picture of potential trophic and climatic controls in this system; a full understanding would need to include (at least) the effects of other predatory fishes (e.g. mackerel Scomber scombrus and cod Gadus morhua), the abundance of which has been severely reduced in the North Sea by overfishing (Jennings et al. 2001, Jennings \& Blanchard 2004), probably contributing to an earlier increase in sandeel abundance through release from a major top-down pressure (Sherman et al. 1981).

In summary, the available evidence suggests that there is substantial spatiotemporal variation in the relative importance of food availability, natural predation and fisheries for the regulation of sandeel abundance in the North Sea, and that top-down and bottom-up mechanisms may have simultaneous direct, indirect and interactive effects. Historical overfishing of predatory fishes such as cod may have led to a system dominated by bottom-up control (cf. Pauly \& Maclean 2003, Halpern et al. 2006), but the recent increases in herring stocks may have reintroduced top-down predation pressure as an important driver of sandeel abundance, at least in some regions. Concluding that climate change was directly responsible for the seabird breeding failures in 2004 may thus be premature.

\section{IMPLICATIONS FOR RESEARCH}

Many marine ecosystems are driven by pronounced variation in the physical environment, such as the extent of sea ice (Hunt et al. 2002), upwelling or major circulation systems like the El Niño Southern Oscillation. In productive temperate shelf systems like the North Sea, effects of physical and climatic drivers are more subtle and difficult to document, although not necessarily less important. Detailed studies of potential drivers are thus needed to understand the dynamics of such systems. It is likely that top-down and bottom-up processes operate simultaneously and interact in the North Sea, with top-down processes potentially being more important at some times and in some areas (such as around Shetland in recent years) than in others (cf. Hunt \& McKinnell 2006). So how can researchers get closer to understanding when and where each type of control dominates? Controlled experiments are impossible in the open sea, and while ecosystem models may be useful, they generally rely on user-specified assumptions about dominant controls in the system and thus have limited ability to distinguish between top-down and bottom-up dominated systems. We believe that careful statistical analysis of multiple longterm data sets covering several trophic layers is the best way forward. Answering critically important questions will often require combining data from several different sources and using complex analytical methods such as multivariate statistics or hierarchical models in a Bayesian framework (Clark 2005). Much progress has been made along these lines in other marine ecosystems recently, such as the Bering Sea (Hunt et al. 2002, Macklin et al. 2002), the Baltic Sea (Bakun 2006, Österblom et al. 2006), the Benguela Current (Cury \& Shannon 2004), the East Scotian Shelf (Choi et al. 2005, Frank et al. 2005) and the Barents Sea (Hjermann 2004, Hjermann et al. 2004). In the North Sea, long-term data on many species from all trophic levels exist, although they are held by many different academic and fishery-sector organisations in several countries. This fragmentation of the scientific community and related issues such as data ownership have delayed the development of an integrative research agenda, although recent short-term networks funded by (e.g.) the European Commission have started the process of integration. The challenge for marine scientists working in the North Sea, and for national and trans-national agencies funding marine research, is to create a permanent joined-up network that will allow effective collaboration across the range of very diverse organisations involved in ecosystem research. A priority issue should be to quantify regional variation at all trophic levels, and for main environmental and anthropogenic drivers. Only through such collaboration can we hope to understand and predict the impacts of fisheries and climate change on this important marine ecosystem (Stenseth et al. 2004, Heath 2005, Boyd et al. 2006).

\section{IMPLICATIONS FOR FISHERIES MANAGEMENT}

In recent years, fisheries management in many parts of the world has started to shift from a traditional single-stock approach, exemplified by the EU Common Fisheries Policy, towards ecosystem-based resource management (Browman \& Stergiou 2004, Barange 2005). The main driver for this shift has been the realisation that fisheries impact not only their tar- 
get species, but also other components of the ecosystem. In order to implement such an approach, it is necessary to understand how extraction of one resource (a top-down pressure at a specific trophic level) affects other species. Predicting such indirect effects requires ecosystem models, such as 'Ecopath with Ecosim' (Christensen \& Walters 2004) or 'ISIS-Fish' (Mahévas \& Pelletier 2004), which allow users to specify trophic relationships among species in detail. As in all modelling exercises, the reliability of the predictions is dependent on the quality of input data and the robustness of the assumptions made in setting up the model. Specifically, erroneous specification of the balance of top-down and bottom-up control in a given predator-prey relationship can lead to misleading predictions (Christensen \& Walters 2004). It is therefore critically important for sustainable management of marine bioresources to understand temporal, spatial and within-system variation in the importance of the 2 basic types of control. We recommend that fisheries modellers and managers examine the sensitivity of model outputs to assumptions about top-down or bottom-up control of key trophic links, such as the herring-sandeel relationship in the North Sea. Closer collaboration between the academic and fisheries research communities will be required to achieve these aims (Barange 2005).

Acknowledgements. We thank F. Daunt, D. Grémillet and 2 anonymous referees for constructive criticism of an earlier draft of this paper. R.W.F was funded by the Leverhulme Trust.

\section{LITERATURE CITED}

Anonymous (2005) Commission regulation (EC) No $1147 / 2005$ of 15 July 2005 prohibiting fishing for sandeel with certain fishing gears in the North Sea and the Skagerrak. Off J Eur Union (Bruxelles) 48:19

Arnott SA, Ruxton GD (2002) Sandeel recruitment in the North Sea: demographic, climatic and trophic effects. Mar Ecol Prog Ser 238:199-210

Arrhenius F (1997) Top-down controls by young-of-the-year herring (Clupea harengus) in the northern Baltic proper. In: Forage fishes in marine ecosystems. Alaska Sea Grant College Program. AK-SG-97-01. University of Alaska, Fairbanks, AK, p 77-86

Bakun A (2006) Wasp-waist populations and marine ecosystem dynamics: navigating the 'predator pit' topographies. Prog Oceanogr 68:271-288

Barange M (2005) Science for sustainable marine bioresources. A report for NERC, DEFRA and SEERAD, GLOBEC International Project Office, Plymouth

Beaugrand G (2004) The North Sea regime shift: evidence, causes, mechanisms and consequences. Prog Oceanogr 60:245-262

Boyd IL, Wanless S, Camphuysen CJ (eds) (2006) Top predators in marine ecosystems: their role in monitoring and management. Cambridge University Press, Cambridge

Browman HI, Stergiou KI (2004) Theme Section: Perspectives on ecosystem-based approaches to the management of marine resources. Mar Ecol Prog Ser 274:269-303

Bull J, Wanless S, Elston DA, Daunt F, Lewis S, Harris MP (2004) Local-scale variability in the diet of black-legged kittiwakes Rissa tridactyla. Ardea 92:43-52

Camphuysen CJ (ed) (2005) Understanding marine foodweb processes: an ecosystem approach to sustainable sandeel fisheries in the North Sea. IMPRESS final report. Royal Netherlands Institute for Sea Research, Texel

Choi JS, Frank KT, Petrie BD, Leggett WC (2005) Integrated assessment of a large marine ecosystem: a case study of the devolution of the Eastern Scotian Shelf, Canada. Oceanogr Mar Biol Annu Rev 43:47-67

Christensen V, Walters CJ (2004) Ecopath with Ecosim: methods, capabilities and limitations. Ecol Model 172:109-139

Clark JS (2005) Why environmental scientists are becoming Bayesians. Ecol Lett 8:2-14

Cook RM (2004) Estimation of the age-specific rate of natural mortality for Shetland sandeels. ICES J Mar Sci 61:159-164

Corten A (2001) Northern distribution of North Sea herring as a response to high water temperatures and/or low food abundance. Fish Res 50:189-204

Cury P, Shannon L (2004) Regime shifts in upwelling ecosystems: observed changes and possible mechanisms in the northern and southern Benguela. Prog Oceanogr 60: 223-243

Davis SE, Nager RG, Furness RW (2005) Food availability affects adult survival as well as breeding success of parasitic jaegers. Ecology 86:1047-1056

Dommasnes A, Melle W, Dalpadado P, Ellertsen B (2004) Herring as a major consumer in the Norwegian Sea. ICES J Mar Sci 61:739-751

Edwards M, Richardson AJ (2004) Impact of climate change on marine pelagic phenology and trophic mismatch. Nature 430:881-884

Edwards M, Beaugrand G, Reid PC, Rowden AA, Jones MB (2002) Ocean climate anomalies and the ecology of the North Sea. Mar Ecol Prog Ser 239:1-10

Frank KT, Petrie B, Choi JS, Leggett WC (2005) Trophic cascades in a formerly cod-dominated ecosystem. Science 308:1621-1623

Frederiksen M, Wanless S, Harris MP, Rothery P, Wilson LJ (2004) The role of industrial fisheries and oceanographic change in the decline of North Sea black-legged kittiwakes. J Appl Ecol 41:1129-1139

Frederiksen M, Wright PJ, Heubeck M, Harris MP, Mavor RA, Wanless S (2005) Regional patterns of kittiwake Rissa tridactyla breeding success are related to variability in sandeel recruitment. Mar Ecol Prog Ser 300:201-211

Frederiksen M, Edwards M, Richardson AJ, Halliday NC, Wanless S (2006) From plankton to top predators: bottomup control of a marine food web across four trophic levels. J Anim Ecol 75:1259-1268

Furness RW (2002) Management implications of interactions between fisheries and sandeel-dependent seabirds and seals in the North Sea. ICES J Mar Sci 59:261-269

Furness RW, Tasker ML (2000) Seabird-fishery interactions: quantifying the sensitivity of seabirds to reductions in sandeel abundance, and identification of key areas for sensitive seabirds in the North Sea. Mar Ecol Prog Ser 202: 253-264

Gallego A, Heath MR, Cook B (2004) The origin and destination of sandeel larvae sampled in the northern North Sea: bio-physical modelling simulation results. Int Counc Explor Sea Comm Meet 2004/P:09:1-13

Gjøsæter H, Bogstad E (1998) Effects of the presence of herring (Clupea harengus) on the stock-recruitment relation- 
ship of Barents Sea capelin (Mallotus villosus) in relation to zooplankton abundance. Fish Res 38:57-71

Grosbois V, Thompson PM (2005) North Atlantic climate variation influences survival in adult fulmars. Oikos 109: 273-290

Halpern BS, Cottenie K, Broitman BR (2006) Strong top-down control in Southern California kelp forest ecosystems. Science 312:1230-1232

Hamer KC, Monaghan P, Uttley JD, Walton P, Burns MD (1993) The influence of food supply on the breeding ecology of kittiwakes Rissa tridactyla in Shetland. Ibis 135: $255-263$

Hardy AC (1924) The herring in relation to its animate environment. Part 1. The food and feeding habits of the herring with special reference to the east coast of England. Fishery Investig, Ser II 7:1-53

Harris MP, Wanless S, Murray S, Mackley E (2004) Isle of May seabird studies in 2004. Joint Nature Conservation Committee/Centre for Ecology and Hydrology, Peterborough

Hays GC, Richardson AJ, Robinson C (2005) Climate change and marine plankton. Trends Ecol Evol 20:337-344

Heath MR (2005) Changes in the structure and function of the North Sea fish foodweb, 1973-2000, and the impacts of fishing and climate. ICES J Mar Sci 62:847-868

Hjermann DØ (2004) Indirect climatic forcing of the Barents Sea capelin: a cohort effect. Mar Ecol Prog Ser 273:229-238

Hjermann DØ, Ottersen G, Stenseth NC (2004) Competition among fishermen and fish causes the collapse of Barents Sea capelin. Proc Natl Acad Sci USA 101:11679-11684

Hunt GL, McKinnell S (2006) Interplay between top-down, bottom-up, and wasp-waist control in marine ecosystems. Prog Oceanogr 68:115-124

Hunt GL, Stabeno P, Walters G, Sinclair E, Brodeur RD, Napp JM, Bond NA (2002) Climate change and control of the southeastern Bering Sea pelagic ecosystem. Deep-Sea Res II 49:5821-5853

ICES (2002) Report of the working group on the assessment of demersal stocks in the North Sea and Skagerrak, June 2001. Int Counc Explor Sea Comm Meet 2002/ACFM:01: $1-554$

ICES (2004) Report of the ICES Advisory Committee on Fishery Management and Advisory Committee on Ecosystems, 2004. ICES advice, Vol 1, Number 2. International Council for the Exploration of the Sea, Copenhagen

ICES (2005) Report of the herring assessment working group for the area south of $62^{\circ} \mathrm{N}$ (HAWG). Int Counc Explor Sea Comm Meet 2005/ACFM:16:40-188

ICES (2006) Report of the study group on recruitment variability in North Sea Planktivorous Fish (SGRECVAP). Int Counc Explor Sea Comm Meet 2006/LRC:03:1-82

Jennings S, Blanchard JL (2004) Fish abundance with no fishing: predictions based on macroecological theory. J Anim Ecol 73:632-642

Jennings S, Kaiser MJ, Reynolds JD (2001) Marine fisheries ecology. Blackwell, Oxford

Johnston JL (1999) A naturalist's Shetland. T \& AD Poyser, London

Last JM (1989) The food of herring, Clupea harengus, in the North Sea, 1983-1986. J Fish Biol 34:489-501

Macklin SA, Hunt GL, Overland JE (2002) Collaborative research on the pelagic ecosystem of the southeastern Bering Sea shelf. Deep-Sea Res II 49:5813-5819

Mahévas S, Pelletier D (2004) ISIS-Fish, a generic and spatially explicit simulation tool for evaluating the impact of management measures on fisheries dynamics. Ecol Model 171:65-84

Mavor RA, Parsons M, Heubeck M, Schmitt S (2005) Seabird numbers and breeding success in Britain and Ireland, 2004. UK Nature Conservation Rep No. 29, Joint Nature Conservation Committee, Peterborough

Munch SB, Snover ML, Watters GM, Mangel M (2005) A unified treatment of top-down and bottom-up control of reproduction in populations. Ecol Lett 8:691-695

Muus BJ, Nielsen JG, Dahlstrøm P, Nyström BO (1999) Sea fish. Scandinavian Fishing Year Book, Hedehusene

Österblom H, Casini M, Olsson O, Bignert A (2006) Fish, seabirds and trophic cascades in the Baltic Sea. Mar Ecol Prog Ser 323:233-238

Pauly D, Maclean J (2003) In a perfect ocean: the state of fisheries and ecosystems in the North Atlantic Ocean. Island Press, Washington, DC

Pedersen SA, Lewy P, Wright P (1999) Assessments of the lesser sandeel (Ammodytes marinus) in the North Sea based on revised stock divisions. Fish Res 41:221-241

Perry AL, Low PJ, Ellis JR, Reynolds JD (2005) Climate change and distribution shifts in marine fishes. Science 308:1912-1915

Proctor R, Wright PJ, Everitt A (1998) Modelling the transport of larval sandeels on the north west European shelf. Fish Oceanogr 7:347-354

Reay PJ (1986) Ammodytidae. In: Whitehead PJP, Bauchot ML, Hureau JC, Nielsen J, Tortonese E (eds) Fishes of the North-eastern Atlantic and the Mediterranean. UNESCO, Paris, p 945-950

Richardson AJ, Schoeman DS (2004) Climate impacts on plankton ecosystems in the Northeast Atlantic. Science 305:1609-1612

Rindorf A, Wanless S, Harris MP (2000) Effects of sandeel availability on the reproductive output of seabirds. Mar Ecol Prog Ser 202:241-252

Royal Commission on Environmental Pollution (2004) Turning the tide: addressing the impact of fisheries on the marine environment. HM Stationery Office, London

Sætre R, Toresen R, Søiland H, Fossum P (2002) The Norwegian spring-spawning herring-spawning, larval drift and larval retention. Sarsia 87:167-178

Scheffer M, Carpenter S, de Young B (2005) Cascading effects of overfishing marine systems. Trends Ecol Evol 11:579-581

Sherman K, Jones C, Sullivan L, Smith W, Berrien P, Ejsymont L (1981) Congruent shifts in sand eel abundance in western and eastern North Atlantic ecosystems. Nature 291: $486-489$

Stenseth NC, Ottersen G, Hurrell JW, Belgrano A (eds) (2004) Marine ecosystems and climate variation: the North Atlantic region. Oxford University Press, Oxford

Wanless S, Harris MP, Greenstreet SPR (1998) Summer sandeel consumption by seabirds breeding in the Firth of Forth, south-east Scotland. ICES J Mar Sci 55:1141-1151

Wanless S, Harris MP, Redman P, Speakman J (2005) Low energy values of fish as a probable cause of a major seabird breeding failure in the North Sea. Mar Ecol Prog Ser 294:1-8

Ware DM, Thomson RE (2005) Bottom-up ecosystem trophic dynamics determine fish production in the northeast Pacific. Science 308:1280-1284

Wilson LJ, Daunt F, Wanless S (2004) Self-feeding and chickprovisioning diet differ in the common guillemot Uria aalge. Ardea 92:197-208

Worm B, Myers RA (2003) Meta-analysis of cod-shrimp interactions reveals top-down control in oceanic food webs. Ecology 84:162-173

Wright PJ, Jensen H, Tuck I (2000) The influence of sediment type on the distribution of the lesser sandeel, Ammodytes marinus. J Sea Res 44:243-256 